\title{
Human Cytomegalovirus is the Cause of Glioblastoma Multiforme
}

\author{
Ilija Barukčić ${ }^{1}$ \\ ${ }^{1}$ Internist, Horandstrasse, DE-26441 Jever, Germany \\ Correspondence: Ilija Barukčić, Horandstrasse, DE-26441 Jever, Germany. Tel: 0049-(0)4466-333. E-mail: \\ Barukcic@t-online.de
}

Received: August 9, 2018; Accepted: September 11, 2018; Published: September 19, 2018

\begin{abstract}
Objective: The relationship between Human cytomegalovirus (HCMV) and glioblastoma multiforme (GBM) is investigated.

Methods: A systematic review and re-analysis of some impressive key studies was conducted aimed to answer the following question. Is there a cause-effect relationship between HCMV and GBM? The method of the conditio sine qua non relationship was used to proof the hypothesis whether the presence of HCMV guarantees the presence of GBM. In other words, without HCMV no GBM. The mathematical formula of the causal relationship k was used to proof the hypothesis, whether there is a cause-effect relationship between HCMV and GBM. Significance was indicated by a p-value of less than 0.05 .
\end{abstract}

Results: The studies analysed were able to provide strict evidence that HCMV is a necessary condition (a conditio sine qua non) of GBM. Furthermore, the cause-effect relationship between HCMV and GBM $(\mathrm{k} \sim+0.8608, \mathrm{p}$ value $<0.0001$ ) was highly significant.

Conclusion: Without a human cytomegalovirus infection no glioblastoma multiforme. Human cytomegalovirus is the cause of glioblastoma multiforme.

Keywords: Cytomegalovirus, Glioblastoma multiforme, Causal relationship

\section{Introduction}

Glioblastoma (Bailey \& Cushing, 1926) multiforme (GBM) is a highly lethal (Zhu et al., 2002), non-curable grade IV diffuse astrocytoma (brain tumour) which is affecting children and adults to such an extent that to date the majority of affected patients are dying from their disease by 2,5 years following diagnosis (Smoll et al., 2013). Glioblastoma multiforme consist primarily of neoplastic astrocytes but includes also other non-neoplastic cell types (Yuan et al., 2004) like neural stem cells, macrophages et cetera. The commonly used World Health Organization (WHO) classification distinguishes different types of glioblastoma multiforme (Louis et al., 2007) due to the presumed cell of origin. In general, glioblastoma multiforme may first appear as a grade 4 glioblastoma (GBM) and is called primary GBM while secondary glioblastoma multiforme develops from a lower grade astrocytoma. The Cancer Genome Atlas (Verhaak et al., 2010) researchers classified four subtypes of GBM as Proneural, Neural, Classical, and Mesenchymal subtypes. In point of fact, even if Glioblastoma multiforme progresses rapidly and is fatal within a very short time despite current therapies, to date the aetiology of glioblastoma multiforme is completely unknown. Among several risk factors supposed to be involved in glioblastoma including exposure to electrical or magnetic fields or ionizing radiation (Ohgaki, 2009) human cytomegalovirus too has been proposed as a contributing agent of glioblastoma multiforme. To our knowledge, HCMV as a member of the Betaherpesvirinae subfamily (Landolfo et al., 2003) is containing a linear double-stranded DNA of $230 \mathrm{~kb}$ surrounded by a proteinaceous tegument, which itself is enclosed by a loosely applied lipid bilayer and contains more than 60 virus-encoded proteins and about 70 host-proteins. The proteins produced by the HCMV can be detected (Landolfo et al., 2003) in various human cellular compartments i.e. by means of immunohistochemistry (IHC). A primary human cytomegalovirus infection leads to a life-long viral persistence. In the latent phase of a HCMV infection HCMV virions are not produced and patients are more or less clinically without symptoms (Priel et al., 2015) but HCMV itself can be present in the monocytes. The seroprevalence of HCMV in the general human population ranges between 50 to $100 \%$ (Gandhi \& Khanna, 2004; Ludwig \& Hengel, 2009; Yi et al., 2013; Najafi et al., 2016). Even a foetus itself is not protected against a vertical transmission. Thus far, HCMV represents the major infectious cause of serious birth defects or developmental disabilities. During maternal primary infection, and to a lesser extent during recurrent infection, human 
cytomegalovirus can translocate the placental barrier and can cause infection of the developing foetus too. Human cytomegalovirus is occurring in $0.5-2 \%$ of pregnancies in Europe and the United States (Kenneson et al., 2007; Wang et al., 2011) and neonatal infections (Fowler et al., 2018) caused by human cytomegalovirus have been reported too. In particular, many breast milk-acquired infections in premature infants are asymptomatic. Several studies demonstrated the presence of human cytomegalovirus in glioblastoma tissues suggesting that HCMV may participate in tumour pathogenesis. But the relationship between GBM and HCMV is controversial because many other studies were unable to detect HCMV in Glioblastoma multiforme tissues.

\section{Material and methods}

\subsection{Material}

\subsubsection{Search Strategy}

To answer the questions addressed in this paper, the electronic database PubMed was searched for appropriate studies conducted in any country which investigated the relationship between human cytomegalovirus and glioblastoma multiforme i. e. sero-epidemiologically or by polymerase chain reaction (PCR) et cetera. The search in PubMed was performed while using some medical key words like "case control study" and "cytomegalovirus" and "glioblastoma multiforme" et cetera. The articles found where saved as a *.txt file while using the support of PubMed. The created *.txt file was converted into a *.pdf file. The abstracts where studied within the *.pdf file. Those articles were considered for a re-view which provided access to data without any data access barrier. Additionally the reference list of identified articles was used as a potential source of articles appropriate for this study.

\subsubsection{The $2 \times 2$ Table}

The meaning of the abbreviations $a_{t}, b_{t}, c_{t}, d_{t}, N_{t}$ of the data table used are explained by a 2 by 2 -table Table 1 .

Table 1. The sample space of a contingency table.

\begin{tabular}{|c|c|c|c|c|}
\hline \multirow{5}{*}{$\begin{array}{l}\text { Condition } A_{t} \\
\text { (risk factor) }\end{array}$} & \multirow{5}{*}{$\begin{array}{l}\text { Yes }=+1 \\
\text { Not }=+0 \\
\text { Total }\end{array}$} & \multicolumn{3}{|c|}{$\begin{array}{l}\text { Conditioned } B_{t} \\
\text { (Outcome) }\end{array}$} \\
\hline & & Yes $=+1$ & Not $=+0$ & Total \\
\hline & & $a_{t}$ & $b_{t}$ & $\mathbf{A}_{\mathbf{t}}$ \\
\hline & & $c_{t}$ & $d_{t}$ & $\underline{\mathrm{A}}_{\mathrm{t}}$ \\
\hline & & $\mathbf{B}_{\mathbf{t}}$ & $\underline{B}_{t}$ & $\mathbf{N}_{t}$ \\
\hline
\end{tabular}

In general it is $\left(a_{t}+b_{t}\right)=A_{t},\left(c_{t}+d_{t}\right)=\underline{A}_{t},\left(a_{t}+c_{t}\right)=B_{t},\left(b_{t}+d_{t}\right)=\underline{B}_{t}$ and $a_{t}+b_{t}+c_{t}+d_{t}=N_{t}$. Equally, it is $B_{t}+\underline{B}_{t}=A_{t}+\underline{A}_{t}$ $=N_{t}$. In this context, it is $p\left(a_{t}\right)=p\left(A_{t} \cap B_{t}\right), p\left(A_{t}\right)=p\left(a_{t}\right)+p\left(b_{t}\right)$ or $p\left(A_{t}\right)=p\left(A_{t} \cap B_{t}\right)+p\left(b_{t}\right)=p\left(A_{t} \cap B_{t}\right)+p\left(A_{t} \cap \underline{B}_{t}\right)$ while $p\left(A_{t}\right)$ is not defined as $p\left(a_{t}\right)$. In the same context, it is $p\left(B_{t}\right)=p\left(a_{t}\right)+p\left(c_{t}\right)=p\left(A_{t} \cap B_{t}\right)+p\left(c_{t}\right)$ and equally in the same respect $p\left(\underline{B}_{t}\right)=1-p\left(B_{t}\right)=p\left(b_{t}\right)+p\left(d_{t}\right)$. Furthermore, the joint probability of $A_{t}$ and $B_{t}$ is denoted in general by $p\left(A_{t} \cap B_{t}\right)$. Thus far, it is $p\left(A_{t} \cap B_{t}\right)=p\left(A_{t}\right)-p\left(b_{t}\right)=p\left(B_{t}\right)-p\left(c_{t}\right)$ or in other words it follows clearly that $p\left(B_{t}\right)+p\left(b_{t}\right)-p\left(c_{t}\right)=p\left(A_{t}\right)$. Thus far, define $\Lambda=p\left(b_{t}\right)-p\left(c_{t}\right)$, Einstein's term $\Lambda$ under conditions of probability theory and we obtain $\mathrm{p}\left(\mathrm{B}_{\mathrm{t}}\right)+\Lambda=\mathrm{p}\left(\mathrm{A}_{\mathrm{t}}\right)$. In general, it is $\mathrm{p}\left(\mathrm{a}_{\mathrm{t}}\right)+\mathrm{p}\left(\mathrm{c}_{\mathrm{t}}\right)+\mathrm{p}\left(\mathrm{b}_{\mathrm{t}}\right)+\mathrm{p}\left(\mathrm{d}_{\mathrm{t}}\right)=1$.

\subsubsection{The Studies not Analyzed}

The studies of Baumgarten et al. (2014), Holdhoff et al. (2017) and Wrensch et al. (2005) which investatigated the relationship between HCMV serostatus and glioblastoma patients were not considered for a review. The study of Yamashita et al. (2014) did not detect HCMV DNA in any of the glioblastoma cases by real-time quantitative PCR (QPCR). Still, while using immunoblotting and immunohistochemistry tissue samples were partly positive according to Yamashita et al. (2014). Thus, it remains unclear the extent to which the methods used by Yamashita et al. (2014) were able to detect the entire HCMV genome when present. Yang et al. (2017) investigated the presence of HCMV genes in human glioblastoma multiforme cases by quantitative PCR using inappropriate HCMV UL73. The data were not re-analyzed.

\subsubsection{The Studies Used to Analyze the Conditio Sine Qua non Relationship between HCMV and GBM}

The studies used to analyze the conditio sine qua non relationship between HCMV and GBM are viewed by the Table 2. 
Table 2. Without human cytalomegalovirus infection no glioblastoma multiforme.

\begin{tabular}{|c|c|c|c|c|c|c|c|c|c|c|c|c|}
\hline Study Id & Year & Country & $\mathrm{N}$ & $a_{t}$ & $b_{t}$ & $\mathrm{c}_{\mathrm{t}}$ & $d_{t}$ & $\mathrm{p}(\mathrm{SINE})$ & $\mathrm{X}^{2}($ Sine $)$ & $\mathrm{k}$ & $\mathrm{X}^{2}(\mathrm{k})$ & p val (k) \\
\hline Cobbs et al. & 2002 & USA & 45 & 22 & 0 & 0 & 23 & 1 & 0.0114 & 1.0000 & 45.0000 & $<0.0001$ \\
\hline Mitchell et al. & 2008 & USA & 90 & 42 & 0 & 3 & 45 & 0.9666667 & 0.1389 & 0.9354 & 78.7500 & $<0.0001$ \\
\hline Scheurer et al. & 2008 & USA & 42 & 21 & 0 & 0 & 21 & 1 & 0.0119 & 1.0000 & 42.0000 & $<0.0001$ \\
\hline Dziurzynski et al. & 2011 & USA & 10 & 5 & 0 & 0 & 5 & 1 & Rule of 3 & 1.0000 & - & - \\
\hline Ranganathan et al. & 2012 & USA & 90 & 73 & 2 & 2 & 13 & 0.9777778 & 0.0300 & 0.8400 & 63.5040 & $<0.0001$ \\
\hline Rahbar et al. & 2012 & Sweden & 160 & 79 & 0 & 1 & 80 & 0.99375 & 0.0031 & 0.9876 & 156.0494 & $<0.0001$ \\
\hline Libard et al. & 2014 & Sweden & 86 & 65 & 0 & 7 & 14 & 0.9186047 & 0.5868 & 0.7758 & 51.7593 & $<0.0001$ \\
\hline Ding et al. & 2014 & China & 73 & 51 & 0 & 16 & 6 & 0.7808219 & 3.5858 & 0.4556 & 15.1547 & 0.0001 \\
\hline Wakefield et al. & 2015 & USA & 48 & 14 & 0 & 10 & 24 & 0.7916667 & 3.7604 & 0.6417 & 19.7647 & $<0.0001$ \\
\hline Xing et al & 2016 & China & 51 & 40 & 0 & 3 & 8 & 0.9411765 & 0.1453 & 0.8225 & 34.5032 & $<0.0001$ \\
\hline Stangherlin et al. & 2016 & Brazil & 23 & 9 & 1 & 1 & 12 & 0.9565217 & 0.0250 & 0.8231 & - & - \\
\hline Slinger et al. & 2010 & Netherlands & 42 & 20 & $12 *$ & 1 & $9 *$ & 0.9761905 & 0.0119 & - & - & - \\
\hline Lucas et al. & 2011 & USA & 90 & 25 & $25^{*}$ & 20 & $20 *$ & 0.7777778 & 8.4500 & - & - & - \\
\hline Bhattacharjee et al. & 2012 & USA & 34 & 16 & $10^{*}$ & 1 & $7 *$ & 0.9705882 & 0.0147 & - & - & - \\
\hline Rahbar et al. & 2013 & Sweden & 150 & 74 & $40 *$ & 1 & $35^{*}$ & 0.9933333 & 0.0033 & - & - & - \\
\hline dos Santos et al. & 2014 & Brazil & 44 & 21 & $12 \%$ & 1 & $10 *$ & 0.9772727 & 0.0114 & - & - & - \\
\hline & & Total & 1078 & 577 & 102 & 67 & 332 & 0.9378479 & 16.19 & & & \\
\hline & & \multicolumn{4}{|l|}{ Alpha $=$} & 0.05 & & & & & & \\
\hline & & \multicolumn{4}{|c|}{ Degrees of freedom (d. f.) $=$} & 15 & & & & & & \\
\hline & & \multicolumn{4}{|c|}{$\mathrm{X}^{2}$ Critical (SINE) $=$} & 24.996 & & & & & & \\
\hline & & \multicolumn{4}{|c|}{$\mathrm{X}^{2}$ Calculated $(\mathrm{SINE})=$} & 16.19 & & & & & & \\
\hline
\end{tabular}

The data as presented by Ranganathan et al. (2012) clearly demonstrated that HCMV genomes are associated with GBM tumors. Even if presentation and illustration of the data of the study of Ranganathan et al. (2012) was difficult to analyze, it was possible to use the data of HCMV UL69. Several of the studies presented above are missing an own control group. Especially the studies of dos Santos et al. (2014), Slinger et al. (2010), Bhattacharjee et al. (2012), Lucas et al. (2011), Holdhoff et al. (2017), Baumgarten et al. (2014) did not provide a suitable control group. This fact has no mathematical influence on the calculation of the chi square value of the necessary condition. Still, we calculated a fictive control group due to the fact that the seroprevalence of HCMV in the general human population ranges between 50 to 100\% (Gandhi \& Khanna, 2004; Ludwig \& Hengel, 2009; Yi et al., 2013; Najafi et al., 2016).

2.1.5 The studies Used to Analyze the Necessary and Sufficient Condition Relationship and the Causal Relationship Between HCMV and GBM

Table 3. The necessary and sufficient condition relationship and the causal relationship between HCVM and GBM

\begin{tabular}{|c|c|c|c|c|c|c|c|c|c|c|c|c|}
\hline Study Id & Year & Country & $\mathrm{N}$ & $a_{t}$ & $b_{t}$ & $\mathrm{c}_{\mathrm{t}}$ & $\mathrm{d}_{\mathrm{t}}$ & $\mathrm{p}(\mathrm{IMP} \wedge \mathrm{SINE})$ & $\mathrm{X}^{2}\left(\mathrm{IMP}^{\wedge} \mathrm{SINE}\right)$ & $\mathrm{k}$ & $X^{2}(\mathrm{k})$ & $\mathrm{p}$ val (k) \\
\hline Cobbs et al. & 2002 & USA & 45 & 22 & 0 & 0 & 23 & 1 & 0.0227 & 1 & 45.00 & $<0.0001$ \\
\hline Mitchell et al. & 2008 & USA & 90 & 42 & 0 & 3 & 45 & 0.966666667 & 0.1448 & 0.935 & 78.75 & $<0.0001$ \\
\hline Scheurer et al. & 2008 & USA & 42 & 21 & 0 & 0 & 21 & 1 & 0.0238 & 1 & 42.00 & $<0.0001$ \\
\hline Dziurzynski et al. & 2011 & USA & 10 & 5 & 0 & 0 & 5 & 1 & Rule of 3 & 1 & 10.00 & 0.0016 \\
\hline Ranganathan et al. & 2012 & USA & 90 & 73 & 2 & 2 & 13 & 0.955555556 & 0.0600 & 0.84 & 63.50 & $<0.0001$ \\
\hline Rahbar et al. & 2012 & Sweden & 160 & 79 & 0 & 1 & 80 & 0.99375 & 0.0063 & 0.9875 & 156.05 & $<0.0001$ \\
\hline Libard et al. & 2014 & Sweden & 86 & 65 & 0 & 7 & 14 & 0.918604651 & 0.5907 & 0.7757 & 51.76 & $<0.0001$ \\
\hline Ding et al. & 2014 & China & 73 & 51 & 0 & 16 & 6 & 0.780821918 & 3.5907 & 0.4556 & 15.15 & 0.0001 \\
\hline Wakefield et al. & 2015 & USA & 48 & 14 & 0 & 10 & 24 & 0.791666667 & 3.7783 & 0.6416 & 19.76 & $<0.0001$ \\
\hline Xing et al. & 2016 & China & 51 & 40 & 0 & 3 & 8 & 0.941176471 & 0.1516 & 0.8225 & 34.50 & $<0.0001$ \\
\hline \multirow[t]{7}{*}{ Stangherlin et al. } & 2016 & Brazil & 23 & 9 & 1 & 1 & 12 & 0.913043478 & Rule of 3 & 0.8230 & 15.58 & 0.0001 \\
\hline & & Total & 718 & 421 & 3 & 43 & 251 & 0.935933148 & 8.3689 & 0.8608 & 532.06 & \\
\hline & & \multicolumn{4}{|l|}{ Alpha $=$} & 0.05 & \multicolumn{3}{|c|}{ Alpha $=$} & \multicolumn{3}{|l|}{0.05} \\
\hline & & \multicolumn{4}{|c|}{ Degrees of freedom $(\mathrm{d} . \mathrm{f})=}$. & 9 & \multicolumn{3}{|c|}{ Degrees of freedom (d. f.) $=$} & \multicolumn{3}{|l|}{11} \\
\hline & & \multicolumn{4}{|c|}{$\mathrm{X}^{2}$ Critical $\left(\right.$ SINE$\left.^{\wedge} \mathbf{I M P}\right)=$} & 16.91 & \multicolumn{3}{|c|}{$X^{2}$ Critical (k) $=$} & \multicolumn{3}{|l|}{19.6751} \\
\hline & \multicolumn{5}{|c|}{$\mathrm{X}^{2}$ Calculated $\left(\mathrm{SINE}^{\wedge} \mathrm{IMP}\right)=$} & 8.368 & \multicolumn{3}{|c|}{$\mathrm{X}^{2}$ Calculated $(\mathrm{k})=$} & 532.06 & & \\
\hline & & & & & & & & & $\mathrm{p}$ value $(\mathrm{k})<$ & 0.0001 & & \\
\hline
\end{tabular}




\subsection{Methods}

\subsubsection{Statistical Analysis}

All statistical analyses (Barukčć. 1989; Barukčć. 2017a; Barukčć. 2017b; Barukčć. 2017c; Barukčć. 2018a; Barukčć. 2018b; Barukčć. 2018c) were performed with Microsoft Excel version 14.0.7166.5000 (32-Bit) Software (Microsoft GmbH. Munich. Germany). The level of significance was set to 0.05 . The probabilities of the contingency table are viewed by the following table (Table 4).

Table 4 . The probabitlities of a contingency table

\begin{tabular}{|c|c|c|c|c|}
\hline \multirow{5}{*}{ Condition $A_{t}$} & \multirow{4}{*}{$\begin{array}{l}\text { Yes }=+1 \\
\text { No }=+0\end{array}$} & \multicolumn{3}{|l|}{$\begin{array}{l}\text { Conditioned } \\
B_{t}\end{array}$} \\
\hline & & Yes $=+1$ & No $=+0$ & Total \\
\hline & & $\mathrm{p}\left(\mathrm{a}_{\mathrm{t}}\right)=\mathrm{p}\left(\mathrm{A}_{\mathrm{t}} \cap \mathrm{B}_{\mathrm{t}}\right)$ & $\mathrm{p}\left(\mathrm{b}_{\mathrm{t}}\right)$ & $p\left(A_{t}\right)$ \\
\hline & & $p\left(c_{t}\right)$ & $\mathrm{p}\left(\mathrm{d}_{\mathrm{t}}\right)$ & $\mathrm{p}\left(\underline{\mathrm{A}}_{\mathrm{t}}\right)$ \\
\hline & & $\mathrm{p}\left(\mathrm{B}_{\mathrm{t}}\right)$ & $\mathrm{p}\left(\underline{B}_{t}\right)$ & 1 \\
\hline
\end{tabular}

2.2.2 Independence

In the case of independence of $A_{t}$ and $B_{t}$ it is generally valid that

$$
p\left(A_{t} \cap B_{t}\right) \equiv p\left(A_{t}\right) \times p\left(B_{t}\right)
$$

\subsubsection{Exclusion ( $A_{t}$ Excludes $B_{t}$ and Vice Versa Relationship)}

The mathematical formula of the exclusion relationship $\left(\mathrm{A}_{t}\right.$ excludes $\mathrm{B}_{t}$ and vice versa) of a population was defined (Barukčć, 2016a; Barukčć, 2017a; Barukčć, 2017b; Barukčć, 2017c; Barukčć, 2018a; Barukčć, 2018b; Barukčć, 2018c) as

$$
\mathrm{p}\left(\mathrm{A}_{\mathrm{t}} \mid \mathrm{B}_{\mathrm{t}}\right) \equiv \frac{\mathrm{b}_{\mathrm{t}}+\mathrm{c}_{\mathrm{t}}+\mathrm{d}_{\mathrm{t}}}{\mathrm{N}_{\mathrm{t}}} \equiv 1-\mathrm{p}\left(\mathrm{a}_{\mathrm{t}}\right) \equiv \mathrm{p}\left(\mathrm{b}_{\mathrm{t}}\right)+\mathrm{p}\left(\mathrm{c}_{\mathrm{t}}\right)+\mathrm{p}\left(\mathrm{d}_{\mathrm{t}}\right) \equiv \mathrm{p}\left(\mathrm{c}_{\mathrm{t}}\right)+\left(1-\mathrm{p}\left(\mathrm{B}_{\mathrm{t}}\right)\right) \equiv \mathrm{p}\left(\mathrm{b}_{\mathrm{t}}\right)+\left(1-\mathrm{p}\left(\mathrm{A}_{\mathrm{t}}\right)\right) \equiv+1
$$

and used to proof the hypothesis: $A_{t}$ excludes $B_{t}$ and vice versa.

\subsubsection{Necessary Condition (Conditio Sine Qua Non)}

The mathematical formula of the necessary condition relationship (conditio sine qua non) of a population was defined (Barukčć, 2016a; Barukčć, 2017a; Barukčć, 2017b; Barukčć, 2017c; Barukčć, 2018a; Barukčć, 2018b; Barukčć, 2018c) as

$$
\mathrm{p}\left(\mathrm{A}_{\mathrm{t}} \leftarrow \mathrm{B}_{\mathrm{t}}\right) \equiv \frac{\mathrm{a}_{\mathrm{t}}+\mathrm{b}_{\mathrm{t}}+\mathrm{d}_{\mathrm{t}}}{\mathrm{N}_{\mathrm{t}}} \equiv \mathrm{p}\left(\mathrm{a}_{\mathrm{t}}\right)+\mathrm{p}\left(\mathrm{b}_{\mathrm{t}}\right)+\mathrm{p}\left(\mathrm{d}_{\mathrm{t}}\right) \equiv \mathrm{p}\left(\mathrm{a}_{\mathrm{t}}\right)+\left(1-\mathrm{p}\left(\mathrm{B}_{\mathrm{t}}\right)\right) \equiv+1
$$

and used to proof the hypothesis: without $\mathrm{A}_{\mathrm{t}}$ no $\mathrm{B}_{\mathrm{t}}$.

\subsubsection{Sufficient Condition (Conditio per Quam)}

The mathematical formula of the sufficient condition relationship (conditio per quam) of a population was defined (Barukčć, 2016a; Barukčć, 2017a; Barukčć, 2017b; Barukčć, 2017c; Barukčć, 2018a; Barukčć, 2018b; Barukčć, 2018c) as

$$
p\left(A_{t} \rightarrow B_{t}\right) \equiv \frac{a_{t}+c_{t}+d_{t}}{N_{t}} \equiv p\left(a_{t}\right)+p\left(c_{t}\right)+p\left(d_{t}\right) \equiv p\left(d_{t}\right)+p\left(B_{t}\right) \equiv+1
$$

and used to proof the hypothesis: if $\mathrm{A}_{\mathrm{t}}$ then $\mathrm{B}_{\mathrm{t}}$.

\subsubsection{The $\mathrm{X}^{2}$ Goodness of Fit Test of a Necessary Condition}

Under conditions where the chi-square goodness of fit test (Pearson, 1900) cannot be used it is possible to use an approximate and conservative (one sided) confidence interval known as the rule of three (Rumke, 1975; Hanley et 
al., 1983; Louis, 1981; Jovanovic et al., 1997). According to the definition of the conditio sine qua non relationship it is

$$
\mathrm{p}\left(\mathrm{A}_{\mathrm{t}} \cap \mathrm{B}_{\mathrm{t}}\right)+\left(1-\mathrm{p}\left(\mathrm{B}_{\mathrm{t}}\right)\right) \equiv+1
$$

or

$$
\mathrm{p}\left(\mathrm{A}_{\mathrm{t}} \cap \mathrm{B}_{\mathrm{t}}\right)+1-\mathrm{p}\left(\mathrm{B}_{\mathrm{t}}\right) \equiv+1
$$

Rearranging this equation, we obtain the essential foundation of the conditio sine qua non relationship as

$$
p\left(A_{t} \cap B_{t}\right)=p\left(B_{t}\right)
$$

and equally our starting point of the derivation of chi-square value of the conditio sine qua non relationship. Multiplying equation before by the population or sample/population size N. it is

$$
\mathrm{N} \times \mathrm{p}\left(\mathrm{A}_{\mathrm{t}} \cap \mathrm{B}_{\mathrm{t}}\right) \equiv \mathrm{N} \times \mathrm{p}\left(\mathrm{B}_{\mathrm{t}}\right)
$$

or

$$
\mathrm{N} \times \mathrm{p}\left(\mathrm{A}_{\mathrm{t}} \cap \mathrm{B}_{\mathrm{t}}\right)-\mathrm{N} \times \mathrm{p}\left(\mathrm{B}_{\mathrm{t}}\right)=0
$$

The square operation yields

$$
\left(N \times p\left(A_{t} \cap B_{t}\right)-N \times p\left(B_{t}\right)\right) \times\left(N \times p\left(A_{t} \cap B_{t}\right)-N \times p\left(B_{t}\right)\right)=0 \times 0
$$

Dividing by $\mathrm{N} \times \mathrm{p}\left(\mathrm{B}_{\mathrm{t}}\right)$ we obtain

which is equivalent with

$$
\frac{\left(N \times p\left(A_{t} \cap B_{t}\right)-N \times p\left(B_{t}\right)\right)^{2}}{N \times p\left(B_{t}\right)}=0
$$

$$
\frac{\left(a_{t}-\left(B_{t}\right)\right)^{2}}{\left(B_{t}\right)}=\frac{\left(a_{t}-\left(a_{t}+c_{t}\right)\right)^{2}}{\left(B_{t}\right)}=\frac{\left(c_{t}\right)^{2}}{\left(B_{t}\right)}=0
$$

Adding $\left(\left(b_{t}+d_{t}\right)-\left(\underline{B}_{t}\right)\right)^{2} \underline{B}_{t}=\left(\left(b_{t}+d_{t}\right)-\left(b_{t}+d_{t}\right)\right)^{2} / \underline{B}_{t}=0$ yields

$$
\frac{\left(c_{t}\right)^{2}}{\left(B_{t}\right)}+0=0+0
$$

Using the continuity correction (Yates, 1934), the chi-square value of a conditio sine qua non distribution before changes to

$$
\chi^{2}(\mathrm{~S} \text { INE }) \equiv \frac{\left(\mathrm{c}_{\mathrm{t}}-\left(\frac{1}{2}\right)\right)^{2}}{\left(\mathrm{~B}_{\mathrm{t}}\right)}+0=0
$$

The use of the continuity correction should follow the rules of statistics as established and valid today. This definition of the $\mathrm{X}^{2}$ distribution of a conditio sine qua non distribution (degrees of freedom = 2-1=1) is more precise than already published formulas. In this context, it is not necessary to improve the definition of the $\mathrm{X}^{2}$ distribution of a conditio per quam distribution as already published. The significance of a causal relationship $\mathrm{k}$ which is $\mathrm{k}>0$ is supported by a significant conditio sine qua non relationship; otherwise the result of a study should be treated with cautious. 


\subsubsection{The $\mathrm{X}^{2}$ Goodness of Fit Test of the Exclusion Relationship}

According to the definition of the exclusion relationship (Barukčć, 2016a; Barukčć, 2017a; Barukčć, 2017b; Barukčć, 2017c; Barukčć, 2018a; Barukčć, 2018b; Barukčć, 2018c) it is

$$
\mathrm{p}\left(\mathrm{b}_{\mathrm{t}}\right)+\mathrm{p}\left(\mathrm{c}_{\mathrm{t}}\right)+\mathrm{p}\left(\mathrm{d}_{\mathrm{t}}\right) \equiv+1
$$

Rearranging this equation, we obtain

$$
\mathrm{p}\left(\mathrm{b}_{\mathrm{t}}\right)=1-\mathrm{p}\left(\mathrm{c}_{\mathrm{t}}\right)-\mathrm{p}\left(\mathrm{d}_{\mathrm{t}}\right)=1-\left(\mathrm{p}\left(\mathrm{c}_{\mathrm{t}}\right)+\mathrm{p}\left(\mathrm{d}_{\mathrm{t}}\right)\right) \equiv 1-\mathrm{p}\left(\underline{\mathrm{A}}_{\mathrm{t}}\right)=\mathrm{p}\left(\mathrm{A}_{\mathrm{t}}\right)
$$

and

$$
\mathrm{p}\left(\mathrm{c}_{\mathrm{t}}\right)=1-\mathrm{p}\left(\mathrm{b}_{\mathrm{t}}\right)-\mathrm{p}\left(\mathrm{d}_{\mathrm{t}}\right) \equiv 1-\left(\mathrm{p}\left(\mathrm{b}_{\mathrm{t}}\right)+\mathrm{p}\left(\mathrm{d}_{\mathrm{t}}\right)\right)=1-\mathrm{p}\left(\underline{\mathrm{B}}_{\mathrm{t}}\right)=\mathrm{p}\left(\mathrm{B}_{\mathrm{t}}\right)
$$

The chi square goodness of fit test of the exclusion relationship can be derived as follows.

$$
\begin{array}{ccc}
N \times p\left(b_{t}\right) & = & N \times p\left(A_{t}\right) \\
\left(N \times p\left(b_{t}\right)-N \times p\left(A_{t}\right)\right) & = & 0 \\
\frac{\left(N \times p\left(b_{t}\right)-N \times p\left(A_{t}\right)\right)^{2}}{N \times p\left(A_{t}\right)} & = & 0 \times 0 \\
\chi^{2}\left(b_{t}\right)=\frac{\left(N \times p\left(b_{t}\right)-N \times p\left(A_{t}\right)\right)^{2}}{N \times p\left(A_{t}\right)}=\frac{\left(b_{t}-\left(a_{t}+b_{t}\right)\right)^{2}}{A_{t}}=\frac{\left(-\left(a_{t}\right)\right)^{2}}{A_{t}} & = & \\
\chi^{2}\left(b_{t}\right)=\frac{\left(-\left(a_{t}\right)-0,5\right)^{2}}{A_{t}} & & \\
& = & 0 \\
& &
\end{array}
$$

and as

$$
\begin{array}{ccc}
N \times p\left(c_{t}\right) & = & N \times p\left(B_{t}\right) \\
\left(N \times p\left(c_{t}\right)-N \times p\left(B_{t}\right)\right) & = & 0 \\
\left(N \times p\left(c_{t}\right)-N \times p\left(B_{t}\right)\right) \times\left(N \times p\left(c_{t}\right)-N \times p\left(B_{t}\right)\right) & = & 0 \times 0 \\
\frac{\left(N \times p\left(c_{t}\right)-N \times p\left(B_{t}\right)\right)^{2}}{N \times p\left(B_{t}\right)} & = & 0 \\
\chi^{2}\left(b_{t}\right)=\frac{\left(N \times p\left(c_{t}\right)-N \times p\left(B_{t}\right)\right)^{2}}{N \times p\left(B_{t}\right)}=\frac{\left(c_{t}-\left(a_{t}+c_{t}\right)\right)^{2}}{B_{t}}=\frac{\left(-\left(a_{t}\right)\right)^{2}}{B_{t}} & = & 0 \\
\chi^{2}\left(c_{t}\right)=\frac{\left(-\left(a_{t}\right)-0,5\right)^{2}}{B_{t}} & =
\end{array}
$$

The chi square value with degree of freedom $2-1=1$ of the exclusion relationship with a continuity correction (Yates, 1934) can be calculated as

$$
\chi^{2}(\text { EXCL })=\frac{\left(-\left(a_{t}\right)-0,5\right)^{2}}{A_{t}}+\frac{\left(-\left(a_{t}\right)-0,5\right)^{2}}{B_{t}}
$$


A significant causal relationship $\mathrm{k}$ which is $\mathbf{k}<\mathbf{0}$ is supported by an exclusion relationship otherwise the results of a study can be interpreted with some cautious. It would be a mistake not to consider all aspects of the relationship between cause and effect. Finally, it should be noted that the fundamental concepts of necessary and sufficient conditions is one of the handy tools which can help us to proof causal claims too.

\subsubsection{The Mathematical Formula of the Causal Relationship k}

The mathematical formula of the causal relationship k (Barukčć, 2016a; Barukčć, 2017a; Barukčć, 2017b; Barukčć, 2017c; Barukčć, 2018a; Barukčć, 2018b; Barukčć, 2018c; Barukčć, 2018d; Barukčć, 2018e; Barukčć, 2018f; Barukčć, 2018g) is defined at every single event, at every single Bernoulli trial $t$, as

$$
k\left(A_{t}, B_{t}\right) \equiv \frac{\left(p\left(A_{t} \cap B_{t}\right)-\left(p\left(A_{t}\right) \times p\left(B_{t}\right)\right)\right)}{\sqrt[2]{\left(p\left(A_{t}\right) \times p\left(\underline{A}_{t}\right)\right) \times\left(p\left(B_{t}\right) \times p\left(\underline{B}_{t}\right)\right)}}
$$

where $A_{t}$ denotes the cause and $B_{t}$ denotes the effect. The chi-square distribution can be applied to determine the significance of causal relationship k. Pearson's concept of correlation (Pearson, 1896) is not identical with causation, causation (Heisenberg, 1927; Einstein \& Podolsky \& Rosen, 1935; Bohr, 1937; Einstein, 1948) is not identical with correlation. In particular, the relationship between correlation and causation has already been discussed in many publications (Wright, 1921; Sober, 2001). Thus far, repeating itself over and over again on this topic is only a waste of time and will not contribute anything new to further scientific progress.

\subsubsection{The 95\% Confidence Interval of the Causal Relationship k}

A confidence interval (CI) of the causal relationship $\mathrm{k}$ calculated from the statistics of the observed data can help to estimate the true value of an unknown population parameter with a certain probability. Let the sample mean $\mathrm{S}$ be

$$
S=\overline{k\left(A_{t}, B_{t}\right)}=\frac{k\left(A_{1}, B_{1}\right)+k\left(A_{2}, B_{2}\right)+\ldots+k\left(A_{n}, B_{n}\right)}{n}=\frac{\sum_{t=+1}^{n} k\left(A_{t}, B_{t}\right)}{n}
$$

Since $k\left(A_{t}, B_{t}\right)$ is Bernoulli $(p)$ distributed with $E\left(k\left(A_{t}, B_{t}\right)\right)=\left(1 \times p\left(k\left(A_{t}, B_{t}\right)\right)\right)+\left(0 \times\left(1-p\left(k\left(A_{t}, B_{t}\right)\right)\right)=p\left(k\left(A_{t}, B_{t}\right)\right)\right.$ where $E\left(k\left(A_{t}, B_{t}\right)\right)$ denotes the expected value of $k\left(A_{t}, B_{t}\right)$ it is

$$
E(S)=p\left(k\left(A_{t}, B_{t}\right)\right) \text { and } \sigma(S)^{2}=\frac{p\left(k\left(A_{t}, B_{t}\right)\right) \times\left(1-p\left(k\left(A_{t}, B_{t}\right)\right)\right)}{n}
$$

where $\sigma(S)^{2}$ denotes the variance of the sampling distribution of $\mathrm{p}\left(\mathrm{k}\left(\mathrm{A}_{\mathrm{t}}, \mathrm{B}_{\mathrm{t}}\right)\right)$. When the sample size is not too small, the central limit theorem based normal approximation can be used to estimate the confidence interval (CI) as

$$
\mathrm{p}\left(\mathrm{k}\left(\mathrm{A}_{\mathrm{t}}, \mathrm{B}_{\mathrm{t}}\right)\right) \pm\left(\mathrm{Z} \times \sqrt[2]{\frac{\mathrm{p}\left(\mathrm{k}\left(\mathrm{A}_{\mathrm{t}}, \mathrm{B}_{\mathrm{t}}\right)\right) \times\left(1-\mathrm{p}\left(\mathrm{k}\left(\mathrm{A}_{\mathrm{t}}, \mathrm{B}_{\mathrm{t}}\right)\right)\right)}{\mathrm{n}}}\right)=\mathrm{p}\left(\mathrm{k}\left(\mathrm{A}_{\mathrm{t}}, \mathrm{B}_{\mathrm{t}}\right)\right) \pm\left(\sqrt[2]{\frac{\mathrm{Z}^{2}}{\mathrm{n}} \times \mathrm{p}\left(\mathrm{k}\left(\mathrm{A}_{\mathrm{t}}, \mathrm{B}_{\mathrm{t}}\right)\right) \times\left(1-\mathrm{p}\left(\mathrm{k}\left(\mathrm{A}_{\mathrm{t}}, \mathrm{B}_{\mathrm{t}}\right)\right)\right)}\right)
$$

where $p\left(k\left(A_{t}, B_{t}\right)\right)$ denotes the proportion of successes in a Bernoulli trial process and $Z$ is the $(1-(\alpha / 2))$ quantile of a standard normal distribution. For a $95 \%$ confidence level $\mathrm{Z} \sim 1.96$, For an unknown standard deviation the Student's $t$ distribution $t$ can be used as the critical value. Still, it is known that $\sigma(\mathrm{S})^{2}$ has the maximum value $(1 /(4 \times n))$ when $\mathrm{p}=1 / 2$ and we have

$$
\mathrm{p}\left(\mathrm{k}\left(\mathrm{A}_{\mathrm{t}}, \mathrm{B}_{\mathrm{t}}\right)\right) \pm\left(\sqrt[2]{\frac{\mathrm{Z}^{2}}{4 \times \mathrm{n}}}\right) \Leftrightarrow \mathrm{p}\left(\mathrm{k}\left(\mathrm{A}_{\mathrm{t}}, \mathrm{B}_{\mathrm{t}}\right)\right) \pm\left(\sqrt[2]{\frac{1.96}{4 \times \mathrm{n}}}\right) \approx \mathrm{p}\left(\mathrm{k}\left(\mathrm{A}_{\mathrm{t}}, \mathrm{B}_{\mathrm{t}}\right)\right) \pm\left(\sqrt[2]{\frac{1}{2 \times \mathrm{n}}}\right)
$$

The proposed approximation is of use even under circumstances where $\mathrm{p}(\ldots)=0.9999 \ldots 999 \sim \mathrm{p}=1$. In this context, we obtain the critical value $p_{\text {critical }}$ approximately as $p_{\text {critical }}=1-(1 /(2 n))^{1 / 2}$. In particular, the concept of Chebyshev's inequality (Tchébychef, 1867) is profound because the same inequality is true for every distribution even if the distribution isn't normal. Thus far, Chebyshev's inequality allows calculating the $95 \%$ confidence of the causal relationship $\mathrm{k}$ and so by the Chebyshev inequality it is 


$$
\mathrm{p}\left\{\mathrm{p}\left(\mathrm{k}\left(\mathrm{A}_{\mathrm{t}}, \mathrm{B}_{\mathrm{t}}\right)\right)-\mathrm{c} \times \sqrt[2]{\sigma(\mathrm{S})^{2}}<\mathrm{S}<\mathrm{p}\left(\mathrm{k}\left(\mathrm{A}_{\mathrm{t}}, \mathrm{B}_{\mathrm{t}}\right)\right)+\mathrm{c} \times \sqrt[2]{\sigma(\mathrm{S})^{2}}\right\} \geq 1-\frac{1}{\mathrm{c}^{2}}
$$

were the right side has the value 0.95 when $\mathrm{c}=(20)^{1 / 2}$. This is the case since $\left(1-\left(1 / \mathrm{c}^{2}\right)\right)=0.95$ or $0.05=\left(1 / \mathrm{c}^{2}\right)$ or $\mathrm{c}^{2}=$ $(1 / 0.05)$ or $\mathrm{c}^{2}=(100 / 5)$ or $\mathrm{c}^{2}=20$ or $\mathrm{c}=(20)^{1 / 2}$. Thus far, if $\mathrm{S}$ does lie in the interval

$$
\left\{\mathrm{p}\left(\mathrm{k}\left(\mathrm{A}_{\mathrm{t}}, \mathrm{B}_{\mathrm{t}}\right)\right)-\sqrt[2]{20 \times \sigma(\mathrm{S})^{2}}, \mathrm{p}\left(\mathrm{k}\left(\mathrm{A}_{\mathrm{t}}, \mathrm{B}_{\mathrm{t}}\right)\right)+\sqrt[2]{20 \times \sigma(\mathrm{S})^{2}}\right\}
$$

then $\mathrm{p}\left(\mathrm{k}\left(\mathrm{A}_{\mathrm{t}}, \mathrm{B}_{\mathrm{t}}\right)\right)$ itself must be in the interval

$$
\left\{\mathrm{S}-\sqrt[2]{20 \times \sigma(\mathrm{S})^{2}}, \mathrm{~S}+\sqrt[2]{20 \times \sigma(\mathrm{S})^{2}}\right\}
$$

which is equally the $95 \%$ confidence interval for an unknown parameter $\mathrm{p}\left(\mathrm{k}\left(\mathrm{A}_{\mathrm{t}}, \mathrm{B}_{\mathrm{t}}\right)\right)$. Again, $\sigma(\mathrm{S})^{2}$ has the maximum value $(1 /(4 \times n))$ when $\mathrm{p}=1 / 2$, so we have

$$
\left\{S-\sqrt[2]{\frac{20 \times 1}{4 \times n}}, S+\sqrt[2]{\frac{20 \times 1}{4 \times n}}\right\}
$$

or the $\mathbf{9 5 \%}$ interval for the causal relationship $\mathrm{k}$ as

$$
\left\{\mathrm{k}\left(\mathrm{A}_{\mathrm{t}}, \mathrm{B}_{\mathrm{t}}\right)-\sqrt[2]{\frac{5}{\mathrm{n}}}, \mathrm{k}\left(\mathrm{A}_{\mathrm{t}}, \mathrm{B}_{\mathrm{t}}\right)+\sqrt[2]{\frac{5}{\mathrm{n}}}\right\}
$$

\subsubsection{Odds Ratio}

The odds ratio (OR) is given (Cornfield, 1951; Edwards, 1963; Mosteller, 1968) by

$$
\operatorname{OR}\left(A_{t}, B_{t}\right) \equiv \frac{a_{t} / b_{t}}{c_{t} / d_{t}}=\frac{a_{t} \times d_{t}}{c_{t} \times b_{t}}
$$

Under conditions were $c_{t}=0$ we have a conditio sine qua non relationship while the odds ratio collapses. Under conditions were $b_{t}=0$ we have a conditio per quam relationship but the odds ratio collapses again, since to date it is not generally accepted (Barukčić \& Barukčić, 2016b; Barukčić, 2018d) to divide by zero. To avoid confusion on this issue, 0.5 is added to the cells $a_{t}, b_{t}, c_{t}, d_{t}$ (Pagano \& Gauvreau, 2018), if zero causes some problems with the calculation of the odds ratio or its standard error which is often very misleading. In point of fact, the odds ratio (OR) is nothing more but Yule's coefficient of association $Q$ (Yule, 1900) re-written (Warrens, 2008) in a non-normalized form and given by

$$
Q\left(A_{t}, B_{t}\right) \equiv \frac{O R\left(A_{t}, B_{t}\right)-1}{O R\left(A_{t}, B_{t}\right)+1}=\frac{\frac{\left(a_{t} \times d_{t}\right)}{\left(b_{t} \times c_{t}\right)}-1}{\frac{\left(a_{t} \times d_{t}\right)}{\left(b_{t} \times c_{t}\right)}+1}=\frac{\frac{\left(a_{t} \times d_{t}\right)-\left(b_{t} \times c_{t}\right)}{\left(b_{t} \times c_{t}\right)}}{\frac{\left(a_{t} \times d_{t}\right)+\left(b_{t} \times c_{t}\right)}{\left(b_{t} \times c_{t}\right)}}=\frac{\left(a_{t} \times d_{t}\right)-\left(b_{t} \times c_{t}\right)}{\left(a_{t} \times d_{t}\right)-\left(b_{t} \times c_{t}\right)}
$$

If $\mathrm{Q}=0$ then there is no association. Yule's coefficient of association, $\mathrm{Q}$, and thus far Odds ratio itself, has been severely criticized by Karl Pearson (1857-1925), the long-time and rarely challenged leader of statistical science and by Heron (Pearson \& Heron, 1913). The standard error and 95\% confidence interval of the odds ratio (OR) can be calculated according to Altman (Altman, 1991). The standard error of the log odds ratio is given by

$$
\operatorname{SE}\left(\ln \left(\mathrm{OR}\left(\mathrm{A}_{\mathrm{t}}, \mathrm{B}_{\mathrm{t}}\right)\right)\right) \equiv \sqrt[1]{\frac{1}{\mathrm{a}_{\mathrm{t}}}+\frac{1}{\mathrm{~b}_{\mathrm{t}}}+\frac{1}{\mathrm{c}_{\mathrm{t}}}+\frac{1}{\mathrm{~d}_{\mathrm{t}}}}
$$


where $\boldsymbol{l n}$ denotes the logarithmus naturalis. The $95 \%$ confidence interval of the odds ratio is given by

$$
95 \% \mathrm{CI}=\exp \left(\ln \left(\mathrm{OR}\left(\mathrm{A}_{t}, \mathrm{~B}_{\mathrm{t}}\right)\right)-\left(1.96 \times \mathrm{SE}\left(\ln \left(\mathrm{OR}\left(\mathrm{A}_{\mathrm{t}}, \mathrm{B}_{\mathrm{t}}\right)\right)\right)\right)\right) \text { to } \exp \left(\ln \left(\mathrm{OR}\left(\mathrm{A}_{\mathrm{t}}, \mathrm{B}_{\mathrm{t}}\right)\right)+\left(1.96 \times \operatorname{SE}\left(\ln \left(\mathrm{OR}\left(\mathrm{A}_{t}, \mathrm{~B}_{\mathrm{t}}\right)\right)\right)\right)\right)
$$

\subsubsection{The Chi Square Distribution}

The following critical values of the chi square distribution as visualized by Table 5 are used in this publication.

Table 5. The critical values of the chi square distribution (degrees of freedom: 1)

\begin{tabular}{llll}
\hline & p-Value & ${\text { One sided } \mathbf{X}^{\mathbf{2}}}$ & Two sided $\mathbf{X}^{\mathbf{2}}$ \\
\cline { 2 - 4 } & 0.1000000000 & 1.642374415 & 2.705543454 \\
& $\mathbf{0 . 0 5 0 0 0 0 0 0 0 0}$ & $\mathbf{2 . 7 0 5 5 4 3 4 5 4}$ & $\mathbf{3 . 8 4 1 4 5 8 8 2 1}$ \\
& 0.0400000000 & 3.06490172 & 4.217884588 \\
& 0.0300000000 & 3.537384596 & 4.709292247 \\
The chi & 0.0200000000 & 4.217884588 & 5.411894431 \\
square & 0.0100000000 & 5.411894431 & 6.634896601 \\
distribution & 0.0010000000 & 9.549535706 & 10.82756617 \\
& 0.0001000000 & 13.83108362 & 15.13670523 \\
& 0.0000100000 & 18.18929348 & 19.51142096 \\
& 0.0000010000 & 22.59504266 & 23.92812698 \\
& 0.0000001000 & 27.03311129 & 28.37398736 \\
& 0.0000000100 & 31.49455797 & 32.84125335 \\
& 0.0000000010 & 35.97368894 & 37.32489311 \\
& 0.0000000001 & 40.46665791 & 41.82145620 \\
\hline
\end{tabular}

\section{Results}

3.1 Without a Human Cytomegalovirus Infection no Glioblastoma Multiforme.

\section{Claims.}

\section{Null hypothesis:}

A cytomegalovirus infection is a necessary condition (a conditio sine qua non) of glioblastoma multiforme. In other words, the sample distribution of the study analyzed agrees with the hypothetical (theoretical) distribution of a necessary condition.

\section{Alternative Hypothesis:}

A cytomegalovirus infection is not a necessary condition (a conditio sine qua non) of glioblastoma multiforme. In other words, the sample distribution of the study analyzed does not agree with the hypothetical (theoretical) distribution of a necessary condition.

The significance level (Alpha) below which the null hypothesis will be rejected is alpha $=0.05$.

\section{Proof.}

The results of the re-analyses of the data reviewed by this article (Table 2) which investigated the relationship between a cytomegalovirus infection and glioblastoma multiforme are viewed by the table (Table 2). Altogether, 16 studies were meta-analyzed while the level of significance was alpha $=0.05$. In toto, 16 out of 16 studies provide significant evidence of a conditio sine qua non relationship between a cytomegalovirus infection and glioblastoma multiforme. The study of Dziurzynski et al. (2011) was significant according to the rule of three. Some of the studies were performed without a control group which had no mathematical effect on the calculation of the chi square value of the conditio sine qua non relationship. The most of the studies analyzed were able to provide evidence of a significant, positive cause effect relationship. In other words, the data analyzed support the Null-hypothesis: without a cytomegalovirus infection no glioblastoma multiforme $\left(\mathrm{X}^{2}\right.$ Calculated (SINE) $=16.19$ and is less than $\mathrm{X}^{2}$ Critical (SINE) $\left.=24.996\right)$. Q. e. d.

\subsection{HCMV is a Necessary and Sufficient Condition of Glioblastoma Multiforme}

\section{Null Hypothesis:}

A cytomegalovirus infection is a necessary and sufficient condition of glioblastoma multiforme. In other words, the sample distribution of the study analyzed agrees with the hypothetical (theoretical) distribution of a necessary and sufficient condition. 


\section{Alternative Hypothesis:}

A cytomegalovirus infection is not a necessary and sufficient condition of glioblastoma multiforme. In other words, the sample distribution of the study analyzed does not agree with the hypothetical (theoretical) distribution of a necessary and sufficient condition.

The significance level (Alpha) below which the null hypothesis will be rejected is alpha $=0.05$.

\section{Proof.}

The results of the re-analyses of the data reviewed by this article (Table 2) which investigated the necessary and sufficient condition relationship between a cytomegalovirus infection and glioblastoma multiforme are viewed by the table (Table 3). Altogether, it was possible to consider 11 studies with a sample size of $\mathrm{N}=718$ for a meta-analyzed while the level of significance was alpha $=0.05$. In toto, 11 out of 11 studies provide significant evidence (Table 3) of a necessary and sufficient conditions relationship $\left(\mathrm{X}^{2}\right.$ Calculated $\left(\mathrm{SINE}^{\wedge} \mathrm{IMP}\right)=8.3689$ is less than $\mathrm{X}^{2}$ Critical $\left.\left(\mathrm{SINE}^{\wedge} \mathrm{IMP}\right)=16.918\right)$ while the causal relationship between a cytomegalovirus infection and glioblastoma multiforme was positive and significant. The studies of Dziurzynski et al. (Dziurzynski et al., 2011) and Stangherlin et al. (Stangherlin et al., 2016) were smaller than $N=30$ and were analyzed according to the rule or three. Especially, the study of Rahbar et al. (Rahbar et al., 2012) detected HCMV-IEA in 79 (99\%) of 80 GBM tumor cells but not in surrounding non-tumor cells. In general, a cytomegalovirus infection is a necessary and sufficient condition of glioblastoma multiforme (Table 3). Q. e. d.

\subsection{HCMV is the Cause of Glioblastoma Multiforme}

Several studies presented missed an appropriate control groups and were not considered for the analyses of the causal relationship between HCMV and GBM (Table 2).

\section{Claims.}

\section{Null Hypothesis:}

A cytomegalovirus infection is not the cause of glioblastoma multiforme. In other words. $\mathrm{k}=0$.

\section{Alternative Hypothesis:}

A cytomegalovirus infection is the cause of glioblastoma multiforme. In other words. $\mathrm{k} \neq 0 . \quad$.

The significance level (Alpha) below which the null hypothesis will be rejected is alpha $=0.05$.

\section{Proof.}

The results of the re-analyses of the data reviewed by this article (Table 2) which investigated the causal relationship between a cytomegalovirus infection and glioblastoma multiforme are viewed by the table (Table 3) Altogether, 11 studies were meta-analyzed while the level of significance was alpha $=0.05$. In toto, 11 from 11 studies provided significant evidence of a causal relationship between a cytomegalovirus infection and glioblastoma multiforme. The studies of Dziurzynski et al. (2011) and Stangherlin et al. (Stangherlin et al., 2016) were smaller than $\mathrm{N}=30$. In the same respect, a cytomegalovirus infection is a necessary (Table 2) and a necessary and sufficient condition of glioblastoma multiforme (Table 3). In other words, without a HCVM infection no GBM. Thus far, the conclusion is inescapable. Human cytomegalovirus is the cause of glioblastoma multiforme $\left(\mathrm{k} \sim 0.8608, \mathrm{X}^{2}\right.$ Calculated $(\mathrm{k})=532.06$ and is greater than $\mathrm{X}^{2}$ Critical $\left.(\mathrm{k})=19.6751\right)$. Q. e. d.

\section{Discussion}

Due to the conflicting reports concerning the presence of the human cytomegalovirus in glioma tissue the association between human cytomegalovirus (HCMV) infection and glioblastoma is still a source of debate. While some studies detected HCMV DNA, RNA and proteins et cetera in GBM tissues others studies (Taha et al., 2016) have not. In most of the previous studies, only a very restricted number of HCMV viral targets with different sensitive techniques (Immunoglobulin G antibodies. immunohistochemical analysis, PCR, in situ hybridization, immunohistochemistry, real-time PCR et cetera ) accompanied by a very different personal skill were analysed.

Thus, the question is justified to which extent was the (entire) viral genome detected at all when present. Furthermore, complicating issues are creating uncertainty about the results of the studies above which detected a strong relationship between HCMV with GBM tumours due to the relatively limited study population and non-randomization. In particular, sample quality (age or method of preservation) and primer selection has substantial effects on the outcome of a study. All these factors may have contributed to the few studies which were not able (Taha et al., 2016) to detect HCMV in GBMs tissues. In contrast to results like these, HCMV presence has been found in about 90-100\% (Cobbs et al., 2002; Mitchell et al., 2008; Rahbar et al., 2012; Söderberg-Nauclér et al., 2013) of GBM tumors. Söderberg-Nauclér et al. (Söderberg-Nauclér et al., 2013) examined more than 250 
cases of glioblastoma while only one of these patients was CMV-negative. Due to the missing control group, the very convincing data of the study of Söderberg-Nauclér et al. (2013) were not considered for causal analysis while the conditio sine qua non relationship is highly significant. Rahbar et al. (2012) detected HCMV infection in 79 of 80 patients (99\%) GBM tumor samples. The surrounding non-tumor cells of the same patient served as the control group. Rahbar et al. (2012) were not able to detect HCMV in any of the controls i. e. HCMV was not detected in surrounding non-tumor cells. The results of the study of Rahbar et al. (2012) are viewed by Table 6. The single study of Rahbar et al. (2012) has provided striking evidence that HCMV infection is a necessary, a sufficient and a necessary and sufficient condition of GBM while the cause effect relationship between HCMV and GBM is highly significant. Thus far and ultimately, according to the study of Rahbar et al. (2012) HCMV is the cause of GBM and much more than this. The evidence of the studies presented cannot be ignored too. In point of fact, several studies did not present a suitable control group (Table 2). Thus far, it was not possible to consider these studies to calculate the causal relationship $\mathrm{k}$ between HCVM and GBM. Besides of this limitation, the missed control group had no mathematical influence on the calculation of the chi square value of the necessary condition distribution. All but the study of Lucas et al. (2011) underdetermine empirically the Null-hypothesis: without HCVM no GBM. In other words, GBM cannot develop without a HCVM infection. It is obvious that the evidence of the relationship between HCVM and GBM is much stronger then outlined just before. In toto, 11 studies with a sample size of $\mathrm{n}=718$ (Table 3) support the Null-hypothesis that HCMV is a necessary and sufficient condition of GBM while the cause effect relationship k between HCMV and GBM is highly significant (Table 3). Ultimately, the evidence documented is extensive, solid and sufficient to justify the hypotheses that HCMV is the cause of GBM.

Table 6. The Study of Rahbar et al. (Rahbar et al., 2012)

\begin{tabular}{|c|c|c|c|c|}
\hline & \multicolumn{4}{|c|}{$\mathrm{GBM}<\mathrm{B}>$} \\
\hline & & Yes & No & Total \\
\hline HCMV-IEA & Yes & 79 & 0 & 79 \\
\hline$<\mathrm{A}>$ & No & 1 & 80 & 81 \\
\hline & Total & 80 & 80 & 160 \\
\hline & & $\begin{array}{r}\mathrm{p} \text { valu } \\
\text { WITHOU } \\
\mathrm{p}(\mathrm{SI} \\
\mathrm{X}^{2}(\mathrm{SI} \\
\\
\mathrm{p} \\
\mathrm{X}^{2} \\
<\mathrm{A}>\mathrm{i} \\
\mathrm{p}\left(\mathrm{SINE}^{\wedge}\right. \\
\mathrm{X}^{2}\left(\mathrm{SINE}^{\wedge}\right.\end{array}$ & $\begin{array}{l}3757 \\
58 \mathrm{E}-3 \\
<\mathrm{B} \\
375 \\
33125 \\
\mathrm{IEN} \\
\\
3316 \\
\mathrm{~d} \text { IMI } \\
375 \\
6628 \mathrm{~S}\end{array}$ & f $<$ B $>$ \\
\hline
\end{tabular}

To date, aggressive treatment (Stupp et al., 2005) of glioblastoma multiforme with surgery, radiation therapy and chemotherapy are relatively ineffective due to the known aggressive nature of GBM and provides only a very limited overall survival benefit for these patients. In fact, there is no effective therapy or cure for glioblastoma multiforme while the life of the patients suffering from this disease is extremely (Smoll et al., 2013) endangered. New therapeutic strategies should be offered to counteract the poor prognosis of GBM. HCMV is the cause of GBM and has a major impact on morbidity, mortality and survival of GBM patients too. In this context, it is necessary to consider a highly effective and simple to practice anti-HCMV therapeutic strategy. HCMV appears to control the PGE 2 synthesis and the expression of COX-2 (Baryawno et al., 2011) in medulloblastomas. Valganciclovir and specific COX-2 inhibitors (Etoricoxib, Celecoxib) are able to prevent HCMV replication and to reduce medulloblastoma tumor cell growth in vitro and in vivo (Baryawno et al., 2011). Anti-CMV treatment has already reduced the growth of medulloblastoma by $72 \%$ in animal model (Baryawno et al., 2011). The double-blind Valcyte Treatment of Glioblastoma Patients in Sweden (VIGAS) clinical trial of valganciclovir (Söderberg-Nauclér et al., 2013) found that cases receiving at least 6 months of antiviral therapy had an significantly increased rate of 2 -year survival $(50 \%$ vs. $20.6 \%, \mathrm{P}<0.001)$ compared with controls. In fact, an optimal treatment of CMV can help to improve the outcome of GBM patient and may focus additionally and primarily on ganciclovir or valganciclovir (Söderberg-Nauclér et al., 2013) and other similar drugs. In particular, drugs like etanercept, etoricoxib (Hung et al., 2017) and leflunomide (John et al., 2004; Suissa et al., 2006) are 
simple to work with and are to some extent effective against human cytomegalovirus too. Ganciclovir, valganciclovir (Söderberg-Nauclér et al., 2013), etanercept, etoricoxib (Hung et al., 2017) and leflunomide (John et al., 2004; Suissa et al., 2006) is of strategic importance at least as an add-on therapy in patients suffering from glioblastoma multiforme. Thus far, it is useful to point out that John et al. (John et al., 2004) documented the efficacy of leflunomide in humans with CMV disease who received loading dose of $100 \mathrm{mg}$ of leflunomide once daily on days $1-3$ and then $20 \mathrm{mg}$ once daily for three months. To date and for preliminary purposes, Etanercept, etoricoxib and leflunomide should become additionally one part of an effective intervention against glioblastoma multiforme. We see the bright colors and the beauty of galaxies so far away from our earth and listen very carefully to the heartbeat of deep space. I stubbornly refuse to accept the conclusions that we are unable to develop a low cost and highly effective vaccine (Inoue et al., 2018) against a CMV infection and even an appropriate DNA CMV therapeutic vaccine too. Historically this hope arises out of the experience that together we have achieved what divided was impossible. In addition, such an undertaking is an urgent and major public health duty too.

\section{Conclusion}

The studies presented in this publication provided a very impressive evidence of a cause effect relationship between HCMV and GBM. In any case, this publication invites us in an overwhelmingly plausible manner to leave aside any doubts and any uncertainty we might have about whether there is a cause effect relationship between HCMV and GBM. For a different view, until a contrary and more convincing experimental objections have been raised against the causal relationship between HCMV and GBM, according to this analysis it is necessary and justified to accept in agreement with the majority of studies presented that human cytomegalovirus is the cause of glioblastoma multiforme.

\section{Acknowledgement}

Dedicated to Celina.

\section{References}

Altman, D. G. (1991). Practical statistics for medical research (1. ed.). London: Chapman and Hall. Retrieved from http://www.loc.gov/catdir/enhancements/fy0646/91124890-d.html

Bailey, P., \& Cushing, H. (1927). A classification of the tumours of the glioma group on a histogenetic basis, with a correlated study of prognosis. By Percival Bailey and Harvey Cushing. Medium 8vo. Pp. 175, with 108 illustrations. 1926. Philadelphia, London, and Montreal: J. B. Lippincott Company. 21s. net. British Journal of Surgery, 14, 554-555. https://doi.org/10.1002/bjs.1800145540

Barukčić, I. (2016a). The Mathematical Formula of the Causal Relationship k. International Journal of Applied Physics and Mathematics, 6, 45-65. https://doi.org/10.17706/ijapm.2016.6.2.45-65

Barukčić, J. P., \& Barukčić, I. (2016b). Anti Aristotle-The Division of Zero by Zero. Journal of Applied Mathematics and Physics, 4, 749-761. https://doi.org/10.4236/jamp.2016.44085

Barukčić, I. (2017a). Anti Bohr — Quantum Theory and Causality. International Journal of Applied Physics and Mathematics, 7, 93-111. https://doi.org/10.17706/ijapm.2017.7.2.93-111

Barukčić, I. (2017b). Die Kausalität. Norderstedt: Books on Demand.

Barukčić, I. (2017c). Theoriae causalitatis principia mathematica. Norderstedt: Books on Demand.

Barukčić, I. (2018a). Epstein Bar Virus-The Cause of Hodgkin's Lymphoma. Journal of Biosciences and Medicines, 6, 75-100. https://doi.org/10.4236/jbm.2018.61008

Barukčić, I. (2018b). Fusobacterium nucleatum-The Cause of Human Colorectal Cancer. Journal of Biosciences and Medicines, 6, 31-69. https://doi.org/10.4236/jbm.2018.63004

Barukčić, I. (2018c). Human Papillomavirus-The Cause of Human Cervical Cancer. Journal of Biosciences and Medicines, 6, 106-125. https://doi.org/10.4236/jbm.2018.64009

Barukčić, I. (2018d). Zero Divided by Zero Equals One. Journal of Applied Mathematics and Physics, 06, 836-853. https://doi.org/10.4236/jamp.2018.64072

Barukčić, I. (2018e) Mycobacterium Avium Subspecies Paratuberculosis -The Cause of Crohn's Disease. Modern Health Science, 1, 19-34. https://doi.org/10.30560/mhs.v1n1p19

Barukčić, I. (2018f) Helicobacter Pylori is the Cause of Gastric Cancer. Modern Health Science, 1, 43-50. https://doi.org/10.30560/mhs.v1n1p43

Barukčić, I. (2018g) Gastric Cancer and Epstein-Barr Virus Infection. A Systematic Review of ISH Based 
Studies. Modern Health Science, 1, 1-18. https://doi.org/10.30560/mhs.v1n2p1

Baryawno, N., Rahbar, A., Wolmer-Solberg, N., Taher, C., Odeberg, J., Darabi, A., Khan, Z., Sveinbjörnsson, B., FuskevÅg, O. M., Segerström, L., Nordenskjöld, M., Siesjö, P., Kogner, P., Johnsen, J. I., \& Söderberg-Nauclér, C. (2011) Detection of human cytomegalovirus in medulloblastomas reveals a potential therapeutic target. The Journal of Clinical Investigation, 121, 4043-55. https://doi.org/10.1172/JCI57147

Bhattacharjee, B., Renzette, N., \& Kowalik, T. F. (2012). Genetic analysis of cytomegalovirus in malignant gliomas. Journal of Virology, 86, 6815-6824. https://doi.org/10.1128/JVI.00015-12

Boeckh, M., Murphy, W. J., \& Peggs, K. S. (2015). Recent advances in cytomegalovirus: an update on pharmacologic and cellular therapies. Biology of Blood and Marrow Transplantation: Journal of the American Society for Blood and Marrow Transplantation, 21, 24-29. https://doi.org/10.1016/j.bbmt.2014.11.002

Bohr, N. (1937). Causality and Complementarity. Philosophy of Science, 4, 289-298. https://doi.org/10.1086/286465

Bongartz, T., Sutton, A. J., Sweeting, M. J., Buchan, I., Matteson, E. L., \& Montori, V. (2006). Anti-TNF antibody therapy in rheumatoid arthritis and the risk of serious infections and malignancies: systematic review and meta-analysis of rare harmful effects in randomized controlled trials. JAMA, 295, 2275-2285. https://doi.org/10.1001/jama.295.19.2275

Cannon, M. J., Schmid, D. S., \& Hyde, T. B. (2010). Review of cytomegalovirus seroprevalence and demographic characteristics associated with infection. Reviews in Medical Virology, 20, 202-213. https://doi.org/10.1002/rmv.655

Choueiter, N. F., Olson, A. K., Shen, D. D., \& Portman, M. A. (2010). Prospective open-label trial of etanercept as adjunctive therapy for kawasaki disease. The Journal of Pediatrics, 157, 960-966.e1. https://doi.org/10.1016/j.jpeds.2010.06.014

Cimino, P. J., Zhao, G., Wang, D., Sehn, J. K., Lewis, J. S., \& Duncavage, E. J. (2014). Detection of viral pathogens in high grade gliomas from unmapped next-generation sequencing data. Experimental and Molecular Pathology, 96, 310-315. https://doi.org/10.1016/j.yexmp.2014.03.010

Cobbs, C. S., Harkins, L., Samanta, M., Gillespie, G. Y., Bharara, S., King, P. H., .. Britt, W. J. (2002). Human Cytomegalovirus Infection and Expression in Human Malignant Glioma. Cancer Research, 62(12), 3347-3350. Retrieved from http://cancerres.aacrjournals.org/content/62/12/3347.full.pdf

Cornfield, J. (1951) A Method of Estimating Comparative Rates from Clinical Data. Applications to Cancer of the Lung, Breast, and Cervix. JNCI: Journal of the National Cancer Institute, 11, 1269-1275. https://doi.org/10.1093/jnci/11.6.1269

Ding, D., Han, S., Wang, Z., Guo, Z., \& Wu, A. (2014). Does the existence of HCMV components predict poor prognosis in glioma? Journal of Neuro-Oncology, 116, 515-522. https://doi.org/10.1007/s11060-013-1350-9

Dos Santos, C. J., Stangherlin, L. M., Figueiredo, E. G., Corrêa, C., Teixeira, M. J., \& da Silva, M. C. C. (2014). High prevalence of HCMV and viral load in tumor tissues and peripheral blood of glioblastoma multiforme patients. Journal of Medical Virology, 86, 1953-1961. https://doi.org/10.1002/jmv.23820

Dziurzynski, K., Chang, S. M., Heimberger, A. B., Kalejta, R. F., McGregor Dallas, S. R., Smit, M., ... Cobbs, C. S. (2012). Consensus on the role of human cytomegalovirus in glioblastoma. Neuro-Oncology, 14, 246-255. https://doi.org/10.1093/neuonc/nor227

Dziurzynski, K., Wei, J., Qiao, W., Hatiboglu, M. A., Kong, L. Y., Wu, A., ... Heimberger, A. B. (2011). Glioma-associated cytomegalovirus mediates subversion of the monocyte lineage to a tumor propagating phenotype. Clinical Cancer Research: An Official Journal of the American Association for Cancer Research, 17, 4642-4649. https://doi.org/10.1158/1078-0432.CCR-11-0414

Edwards, A. W. F. (1963). The Measure of Association in a $2 \times 2$ Table. Journal of the Royal Statistical Society. Series a (General), 126, 109-114. https://doi.org/10.2307/2982448

Einstein, A. (1948). Quanten-Mechanik und Wirklichkeit. Dialectica, 2, 320-324. https://doi.org/10.1111/j.1746-8361.1948.tb00704.x

Einstein, A., Podolsky, B., \& Rosen, N. (1935). Can Quantum-Mechanical Description of Physical Reality Be Considered Complete? Physical Review, 47, 777-780. https://doi.org/10.1103/PhysRev.47.777 
Fowler, K. B., Ross, S. A., Shimamura, M., Ahmed, A., Palmer, A. L., Michaels, M. G., ... Boppana, S. (2018). Racial and Ethnic Differences in the Prevalence of Congenital Cytomegalovirus Infection. The Journal of Pediatrics. Advance online publication. https://doi.org/10.1016/j.jpeds.2018.04.043

Gandhi, M. K., \& Khanna, R. (2004). Human cytomegalovirus: Clinical aspects, immune regulation, and emerging treatments. The Lancet Infectious Diseases, 4, 725-738. https://doi.org/10.1016/S1473-3099(04)01202-2

Garcia-Martinez, A., Alenda, C., Irles, E., Ochoa, E., Quintanar, T., Rodriguez-Lescure, A., ... Barbera, V. M. (2017). Lack of cytomegalovirus detection in human glioma. Virology Journal, 14, 216. https://doi.org/10.1186/s12985-017-0885-3

Gupta, D. K., Mahapatra, A., Sharma, M., \& Kasliwal, M. (2007). Congenital glioblastoma multiforme: A case report and review of literature. Journal of Pediatric Neurosciences, 2, 69. https://doi.org/10.4103/1817-1745.36766

Haerter, G., Manfras, B. J., Jong-Hesse, Y. de, Wilts, H., Mertens, T., Kern, P., \& Schmitt, M. (2004). Cytomegalovirus retinitis in a patient treated with anti-tumor necrosis factor alpha antibody therapy for rheumatoid arthritis. Clinical Infectious Diseases : an Official Publication of the Infectious Diseases Society of America, 39, e88-94. https://doi.org/10.1086/425123

Han, S., Wang, P. F., Xing, Y. X., Song, H. W., Yao, K., \& Lin, Z. X. (2018). Human Cytomegalovirus (HCMV) infection was not correlated with overall survival in glioblastomas. Neoplasma, 65, 431-435. https://doi.org/10.4149/neo_2018_170124N59

Hanley, J. A. (1983). If Nothing Goes Wrong, Is Everything All Right? JAMA, 249, 1743. https://doi.org/10.1001/jama.1983.03330370053031

Heisenberg, W. (1927). Über den anschaulichen Inhalt der quantentheoretischen Kinematik und Mechanik. Zeitschrift Fr Physik, 43, 172-198. https://doi.org/10.1007/BF01397280

Holdhoff, M., Guner, G., Rodriguez, F. J., Hicks, J. L., Zheng, Q., Forman, M. S., ... Arav-Boger, R. (2017). Absence of Cytomegalovirus in Glioblastoma and Other High-grade Gliomas by Real-time PCR, Immunohistochemistry, and In Situ Hybridization. Clinical Cancer Research: An Official Journal of the American Association for Cancer Research, 23, 3150-3157. https://doi.org/10.1158/1078-0432.CCR-16-1490

Holdhoff, M., Rothenberger, R., \& Browner, I. E. (2018). Glioblastoma in older adults. Aging, 10, 154-155. https://doi.org/10.18632/aging.101377

Hui-Yuen, J. S., Duong, T. T., \& Yeung, R. S. M. (2006). TNF- Is Necessary for Induction of Coronary Artery Inflammation and Aneurysm Formation in an Animal Model of Kawasaki Disease. The Journal of Immunology, 176, 6294-6301. https://doi.org/10.4049/jimmunol.176.10.6294

Hung, Y. M., Lin, L., Chen, C. M., Chiou, J. Y., Wang, Y. H., Wang, P. Y. P., \& Wei, J. C. C. (2017). The effect of anti-rheumatic medications for coronary artery diseases risk in patients with rheumatoid arthritis might be changed over time: A nationwide population-based cohort study. PloS One, 12, e0179081. https://doi.org/10.1371/journal.pone.0179081

John, G. T., Manivannan, J., Chandy, S., Peter, S., \& Jacob, C. K. (2004). Leflunomide therapy for cytomegalovirus disease in renal allograft recepients. Transplantation, 77, 1460-1461. https://doi.org/10.1097/01.TP.0000122185.64004.89

Johnson, T. S., Abrams, Z. B., Mo, X., Zhang, Y., \& Huang, K. (2017). Lack of human cytomegalovirus expression in single cells from glioblastoma tumors and cell lines. Journal of Neurovirology, 23, 671-678. https://doi.org/10.1007/s13365-017-0543-y

Jovanovic, B. D., \& Levy, P. S. (1997). A Look at the Rule of Three. The American Statistician, 51, 137. https://doi.org/10.2307/2685405

Kenneson, A., \& Cannon, M. J. (2007). Review and meta-analysis of the epidemiology of congenital cytomegalovirus (CMV) infection. Reviews in Medical Virology, 17, 253-276. https://doi.org/10.1002/rmv.535

Kolmogoroff, A. (1933). Grundbegriffe der Wahrscheinlichkeitsrechnung. Ergebnisse der Mathematik und Ihrer Grenzgebiete: Vol. 2. Berlin, Heidelberg, s.l.: Springer Berlin Heidelberg. Retrieved from https://doi.org/10.1007/978-3-642-49888-6 
Landolfo, S., Gariglio, M., Gribaudo, G., \& Lembo, D. (2003). The human cytomegalovirus. Pharmacology \& Therapeutics, 98, 269-297. https://doi.org/10.1016/S0163-7258(03)00034-2

Liao, T. L., Chen, Y. M., Liu, H. J., \& Chen, D. Y. (2017). Risk and severity of herpes zoster in patients with rheumatoid arthritis receiving different immunosuppressive medications: a case-control study in Asia. $B M J$ Open, 7, e014032. https://doi.org/10.1136/bmjopen-2016-014032

Libard, S., Popova, S. N., Amini, R.-M., Kärjä, V., Pietiläinen, T., Hämäläinen, K. M., ... Alafuzoff, I. (2014). Human cytomegalovirus tegument protein pp65 is detected in all intra- and extra-axial brain tumours independent of the tumour type or grade. PloS One, 9, e108861. https://doi.org/10.1371/journal.pone.0108861

Louis, T. A. (1981). Confidence Intervals for a Binomial Parameter after Observing No Successes. The American Statistician, 35, 154. https://doi.org/10.1080/00031305.1981.10479337

Louis, D. N., Ohgaki, H., Wiestler, O. D., Cavenee, W. K., Burger, P. C., Jouvet, A., .. Kleihues, P. (2007). The 2007 WHO classification of tumours of the central nervous system. Acta Neuropathologica, 114, 97-109. https://doi.org/10.1007/s00401-007-0243-4

Lu, C. H., Tsai, J. H., Wu, M. Z., Yu, C. L., \& Hsieh, S. C. (2015). Can leflunomide play a role in cytomegalovirus disease prophylaxis besides its antirheumatic effects? Antiviral Therapy, 20, 93-96. https://doi.org/10.3851/IMP2796

Lucas, K. G., Bao, L., Bruggeman, R., Dunham, K., \& Specht, C. (2011). The detection of CMV pp65 and IE1 in glioblastoma multiforme. Journal of Neuro-Oncology, 103, 231-238. https://doi.org/10.1007/s11060-010-0383-6

Ludwig, A., \& Hengel, H. (2009). Epidemiological impact and disease burden of congenital cytomegalovirus infection in Europe. Euro Surveillance: Bulletin Europeen Sur Les Maladies Transmissibles = European Communicable Disease Bulletin, 14, 26-32. https://doi.org/10.2807/ese.14.09.19140-en

McFaline-Figueroa, J. R., \& Wen, P. Y. (2017). The Viral Connection to Glioblastoma. Current Infectious Disease Reports, 19, 5. https://doi.org/10.1007/s11908-017-0563-z

Mitchell, D. A., Xie, W., Schmittling, R., Learn, C., Friedman, A., McLendon, R. E., \& Sampson, J. H. (2008). Sensitive detection of human cytomegalovirus in tumors and peripheral blood of patients diagnosed with glioblastoma. Neuro-Oncology, 10, 10-18. https://doi.org/10.1215/15228517-2007-035

Mosteller, F. (1968). Association and Estimation in Contingency Tables. Journal of the American Statistical Association, 63, 1. https://doi.org/10.2307/2283825

Nagasawa, D. T., Chow, F., Yew, A., Kim, W., Cremer, N., \& Yang, I. (2012). Temozolomide and Other Potential Agents for the Treatment of Glioblastoma Multiforme. Neurosurgery Clinics of North America, 23, 307-322. https://doi.org/10.1016/j.nec.2012.01.007

Najafi, S., Ghane, M., Poortahmasebi, V., Jazayeri, S. M., \& Yousefzadeh-Chabok, S. (2016). Prevalence of Cytomegalovirus in Patients With Multiple Sclerosis: A Case-Control Study in Northern Iran. Jundishapur Journal of Microbiology, 9, e36582. https://doi.org/10.5812/jjm.36582

Ohgaki, H. (2009). Epidemiology of brain tumors. Methods in Molecular Biology (Clifton, N.J.), 472, 323-342. https://doi.org/10.1007/978-1-60327-492-0_14

Olsson, J., Kok, E., Adolfsson, R., Lövheim, H., \& Elgh, F. (2017). Herpes virus seroepidemiology in the adult Swedish population. Immunity \& Ageing: I \& a, 14, 10. https://doi.org/10.1186/s12979-017-0093-4

Pagano, M., \& Gauvreau, K. (2018). Principles of Biostatistics, Second Edition (2nd ed.). Milton: CRC Press. Retrieved from https://ebookcentral.proquest.com/lib/gbv/detail.action?docID=5301930

Pearson, K. (1896). Mathematical Contributions to the Theory of Evolution. III. Regression, Heredity, and Panmixia. Philosophical Transactions of the Royal Society a: Mathematical, Physical and Engineering Sciences, 187, 253-318. https://doi.org/10.1098/rsta.1896.0007

Pearson, K. (1900). X. On the criterion that a given system of deviations from the probable in the case of a correlated system of variables is such that it can be reasonably supposed to have arisen from random sampling. The London, Edinburgh, and Dublin Philosophical Magazine and Journal of Science, 50, 157-175. https://doi.org/10.1080/14786440009463897

Pearson, K. (1904). On the theory of contingency and its relation to association and normal correlation. London, 
1-46. Retrieved from https://archive.org/details/cu31924003064833

Petersen, B., \& Lorentzen, H. (2008). Cytomegalovirus complicating biological immunosuppressive therapy in two patients with psoriasis receiving treatment with etanercept or efalizumab. Acta Dermato-Venereologica, 88, 523-524. https://doi.org/10.2340/00015555-0491

Poltermann, S., Schlehofer, B., Steindorf, K., Schnitzler, P., Geletneky, K., \& Schlehofer, J. R. (2006). Lack of association of herpesviruses with brain tumors. Journal of Neurovirology, 12, 90-99. https://doi.org/10.1080/13550280600654573

Prasad, V., Rajesh, A., Purohit, A., \& Uppin, M. (2017). A rare case of congenital glioblastoma with atypical presentation in an eleven month-old infant: Case report with review of literature. Asian Journal of Neurosurgery, 12, 72. https://doi.org/10.4103/1793-5482.145103

Priel, E., Wohl, A., Teperberg, M., Nass, D., \& Cohen, Z. R. (2015). Human cytomegalovirus viral load in tumor and peripheral blood samples of patients with malignant gliomas. Journal of Clinical Neuroscience: Official Journal of the Neurosurgical Society of Australasia, 22, 326-330. https://doi.org/10.1016/j.jocn.2014.06.099

Rahbar, A., Stragliotto, G., Orrego, A., Peredo, I., Taher, C., Willems, J., \& Söderberg-Naucler, C. (2012) Low levels of Human Cytomegalovirus Infection in Glioblastoma multiforme associates with patient survival; -a case-control study. Herpesviridae, 3(3). https://doi.org/10.1186/2042-4280-3-3

Rahbar, A., Orrego, A., Peredo, I., Dzabic, M., Wolmer-Solberg, N., Strååt, K., ... Söderberg-Nauclér, C. (2013) Human cytomegalovirus infection levels in glioblastoma multiforme are of prognostic value for survival. Journal of Clinical Virology: The Official Publication of the Pan American Society for Clinical Virology, 57, 36-42. https://doi.org/10.1016/j.jcv.2012.12.018

Ranganathan, P., Clark, P. A., Kuo, J. S., Salamat, M. S., \& Kalejta, R. F. (2012). Significant association of multiple human cytomegalovirus genomic Loci with glioblastoma multiforme samples. Journal of Virology, 86, 854-864. https://doi.org/10.1128/JVI.06097-11

Rumke, C. L. (1975). Implications of the Statement: No Side Effects Were Observed. New England Journal of Medicine, 292, 372-373. https://doi.org/10.1056/NEJM197502132920723

Scheurer, M. E., Bondy, M. L., Aldape, K. D., Albrecht, T., \& El-Zein, R. (2008). Detection of human cytomegalovirus in different histological types of gliomas. Acta Neuropathologica, 116, 79-86. https://doi.org/10.1007/s00401-008-0359-1

Schleiss, M. R. (2013). Cytomegalovirus in the neonate: immune correlates of infection and protection. Clinical \& Developmental Immunology, 2013, 501801. https://doi.org/10.1155/2013/501801

Sinclair, J., \& Reeves, M. (2014). The intimate relationship between human cytomegalovirus and the dendritic cell lineage. Frontiers in Microbiology, 5, 595. https://doi.org/10.3389/fmicb.2014.00389

Slinger, E., Maussang, D., Schreiber, A., Siderius, M., Rahbar, A., Fraile-Ramos, A., ... Smit, M. J. (2010). HCMV-encoded chemokine receptor US28 mediates proliferative signaling through the IL-6-STAT3 axis. Science Signaling, 3, ra58. https://doi.org/10.1126/scisignal.2001180

Smoll, N. R., Schaller, K., \& Gautschi, O. P. (2013). Long-term survival of patients with glioblastoma multiforme (GBM). Journal of Clinical Neuroscience: Official Journal of the Neurosurgical Society of Australasia, 20, 670-675. https://doi.org/10.1016/j.jocn.2012.05.040

Sober, E. (2001). Venetian Sea Levels, British Bread Prices, and the Principle of the Common Cause. The British Journal for the Philosophy of Science, 52, 331-346. https://doi.org/10.1093/bjps/52.2.331

Söderberg-Nauclér, C., Rahbar, A., \& Stragliotto, G. (2013) Survival in patients with glioblastoma receiving valganciclovir. The New England Journal of Medicine, 369, 985-986. https://doi.org/10.1056/NEJMc1302145

Söderberg-Nauclér, C. (2015) Cytomegalovirus in human brain tumors: Role in pathogenesis and potential treatment options. World Journal of Experimental Medicine, 5(1). https://doi.org/10.5493/wjem.v5.i1.1

Solomon, I. H., Ramkissoon, S. H., Milner, D. A., \& Folkerth, R. D. (2014). Cytomegalovirus and glioblastoma: a review of evidence for their association and indications for testing and treatment. Journal of $\begin{array}{lllll}\text { Neuropathology and } & \text { Experimental }\end{array}$ https://doi.org/10.1097/NEN.0000000000000125

Strååt, K., Liu, C., Rahbar, A., Zhu, Q., Liu, L., Wolmer-Solberg, N., ... Xu, D. (2009). Activation of telomerase 
by human cytomegalovirus. Journal of the National Cancer Institute, 101, 488-497. https://doi.org/10.1093/jnci/djp031

Stragliotto, G., Rahbar, A., Solberg, N. W., Lilja, A., Taher, C., Orrego, A., ... Söderberg-Nauclér, C. (2013). Effects of valganciclovir as an add-on therapy in patients with cytomegalovirus-positive glioblastoma: A randomized, double-blind, hypothesis-generating study. International Journal of Cancer, 133, 1204-1213. https://doi.org/10.1002/ijc.28111

Stupp, R., Mason, W. P., van den Bent, M. J., Weller, M., Fisher, B., Taphoorn, M. J. B., ... Mirimanoff, R. O. (2005). Radiotherapy plus concomitant and adjuvant temozolomide for glioblastoma. The New England Journal of Medicine, 352, 987-996. https://doi.org/10.1056/NEJMoa043330

Sudarsanam, T. D., Sahni, R. D., \& John, G. T. (2006). Leflunomide: A possible alternative for gangciclovir sensitive and resistant cytomegalovirus infections. Postgraduate Medical Journal, 82, 313-314. https://doi.org/10.1136/pgmj.2005.038521

Suissa, S., Bernatsky, S., \& Hudson, M. (2006). Antirheumatic drug use and the risk of acute myocardial infarction. Arthritis and Rheumatism, 55, 531-536. https://doi.org/10.1002/art.22094

Taha, M. S., Abdalhamid, B. A., El-Badawy, S. A., Sorour, Y. M., Almsned, F. M., \& Al-Abbadi, M. A. (2016). Expression of cytomegalovirus in glioblastoma multiforme: Myth or reality? British Journal of Neurosurgery, 30, 307-312. https://doi.org/10.3109/02688697.2015.1119241

Urbańska, K., Sokołowska, J., Szmidt, M., \& Sysa, P. (2014). Review Glioblastoma multiforme - an overview. Wspótczesna Onkologia, 5, 307-312. https://doi.org/10.5114/wo.2014.40559

Verhaak, R. G. W., Hoadley, K. A., Purdom, E., Wang, V., Qi, Y., Wilkerson, M. D., ... Hayes, D. N. (2010). Integrated genomic analysis identifies clinically relevant subtypes of glioblastoma characterized by abnormalities in PDGFRA, IDH1, EGFR, and NF1. Cancer Cell, 17, 98-110. https://doi.org/10.1016/j.ccr.2009.12.020

Verkaik, N. J., Hoek, R. A. S., van Bergeijk, H., van Hal, P. T. W., Schipper, M. E. I., Pas, S. D., ... Murk, J. L. (2013). Leflunomide as part of the treatment for multidrug-resistant cytomegalovirus disease after lung transplantation: case report and review of the literature. Transplant Infectious Disease: An Official Journal of the Transplantation Society, 15, E243-9. https://doi.org/10.1111/tid.12156

Waldman, W. J., Knight, D. A., Blinder, L., Shen, J., Lurain, N. S., Miller, D. M., ... Chong, A. S. (1999). Inhibition of cytomegalovirus in vitro and in vivo by the experimental immunosuppressive agent leflunomide. Intervirology, 42, 412-418. https://doi.org/10.1159/000053979

Wang, C., Zhang, X., Bialek, S., \& Cannon, M. J. (2011). Attribution of congenital cytomegalovirus infection to primary versus non-primary maternal infection. Clinical Infectious Diseases: An Official Publication of the Infectious Diseases Society of America, 52, e11-3. https://doi.org/10.1093/cid/ciq085

Warrens, M. J. (2008). On Association Coefficients for $2 \times 2$ Tables and Properties That Do Not Depend on the Marginal Distributions. Psychometrika, 73, 777-789. https://doi.org/10.1007/s11336-008-9070-3

Weller, M., van den Bent, M., Tonn, J. C., Stupp, R., Preusser, M., Cohen-Jonathan-Moyal, E., ... Wick, W. (2017). European Association for Neuro-Oncology (EANO) guideline on the diagnosis and treatment of adult astrocytic and oligodendroglial gliomas. The Lancet Oncology, 18, e315-e329. https://doi.org/10.1016/S1470-2045(17)30194-8

Wrensch, M., Weinberg, A., Wiencke, J., Miike, R., Sison, J., Wiemels, J., ... Kelsey, K. (2005). History of chickenpox and shingles and prevalence of antibodies to varicella-zoster virus and three other herpesviruses among adults with glioma and controls. American Journal of Epidemiology, 161, 929-938. https://doi.org/10.1093/aje/kwi119

Wright, S. (1921). Correlation and Causation. Journal of Agricultural Research, 20, 557-585.

Xing, Y., Wang, Y., Wang, S., Wang, X., Fan, D., Zhou, D., \& An, J. (2016). Human cytomegalovirus infection contributes to glioma disease progression via upregulating endocan expression. Translational Research: the Journal of Laboratory and Clinical Medicine, 177, 113-126. https://doi.org/10.1016/j.trsl.2016.06.008

Yamane, T. (Ed.) (1964). Statistics. An introductory analysis: Harper International Edition.

Yamashita, Y., Ito, Y., Isomura, H., Takemura, N., Okamoto, A., Motomura, K., ... Tsurumi, T. (2014). Lack of presence of the human cytomegalovirus in human glioblastoma. Modern Pathology: An Official Journal of the United States and Canadian Academy of Pathology, Inc, 27, 922-929. 
https://doi.org/10.1038/modpathol.2013.219

Yang, C. F., Ho, H. L., Lin, S. C., Hsu, C. Y., \& Ho, D. M. T. (2017). Detection of human cytomegalovirus in glioblastoma among Taiwanese subjects. PloS One, 12, e0179366. https://doi.org/10.1371/journal.pone.0179366

Yates, F. (1934). Contingency Tables Involving Small Numbers and the $\mathrm{X}^{2}$ Test. The Journal of the Royal Statistical Society (Supplement), 1, 217-235. https://doi.org/10.2307/2983604

Yi, F., Zhao, J., Luckheeram, R. V., Lei, Y., Wang, C., Huang, S., ... Xia, B. (2013). The prevalence and risk factors of cytomegalovirus infection in inflammatory bowel disease in Wuhan, Central China. Virology Journal, 10(43). https://doi.org/10.1186/1743-422X-10-43

Yuan, X., Curtin, J., Xiong, Y., Liu, G., Waschsmann-Hogiu, S., Farkas, D. L., ... Yu, J. S. (2004). Isolation of cancer stem cells from adult glioblastoma multiforme. Oncogene, 23, 9392-9400. https://doi.org/10.1038/sj.onc.1208311

Yule, G. U. (1900). On the Association of Attributes in Statistics: With Illustrations from the Material of the Childhood Society, \&c. Philosophical Transactions of the Royal Society a: Mathematical, Physical and Engineering Sciences, 194, 257-319. https://doi.org/10.1098/rsta.1900.0019

Zavala-Vega, S., Castro-Escarpulli, G., Hernández-Santos, H., Salinas-Lara, C., Palma, I., Mejía-Aranguré, J. M., ... Arellano-Galindo, J. (2017). An overview of the infection of CMV, HSV 1/2 and EBV in Mexican patients with glioblastoma multiforme. Pathology, Research and Practice, 213, 271-276. https://doi.org/10.1016/j.prp.2016.12.006

Zhu, Y., \& Parada, L. F. (2002). The molecular and genetic basis of neurological tumours. Nature Reviews. Cancer, 2, 616-626. https://doi.org/10.1038/nrc866

\section{Copyrights}

Copyright for this article is retained by the author(s), with first publication rights granted to the journal.

This is an open-access article distributed under the terms and conditions of the Creative Commons Attribution license (http://creativecommons.org/licenses/by/4.0/). 